\author{
Associate Professor Silvia Elena IACOB, PhD \\ E-mail: popescusilviaelena@yahoo.com \\ The Bucharest University of Economic Studies \\ Professor Mihai MIEILĂ, PhD \\ E-mail: m_mieila@yahoo.com \\ Valahia" University of Târgovişte \\ Associate Professor Marcela ȘTEFAN,PhD \\ E-mail: stefanmarcela57@yahoo.com \\ The Bucharest University of Economic Studies \\ Ioan Radu PETRARIU, PhD student \\ E-mail: ioanradupetrariu@gmail.com \\ The Bucharest University of Economic Studies
}

\title{
SIGNIFICANT INTERDEPENDENCIES OF THE SERVICES \\ SECTOR IN THE ROMANIAN ECONOMY: AN ANALYTICAL EXAMINATION
}

\begin{abstract}
The aim of present paper is to present the recent defining evolutions of the services sector in Romanian economy. In this respect, the paper contains a review of the evolution in relative contribution of the main economic sectors in Romanian economy and the evolution in total turnover for the tertiary sector in the last twenty years. Further, are examined the contribution of the sector to economic growth and the correlation between the share of employment and the sectoral growth. In this context, another investigated paradigm regards the relation between the share of employment in services and the share of women participation in the labor force, both in the international context and for the Romanian economy. All the analytical examinations presented returned significant results. The conclusions outline the results and contain several future research directions..

Keywords: Services sector, Gross Domestic Product, Growth rate, Labor force participation, Employment.

JEL Classification: C200, E240, F430, J210

1. Introduction

The global trend of growing contribution of services in national economies is considered in the literature as an indicator of the economic progress and development (Urquhart, 1984; Ahmed and Ahsan, 2011; Mujahid and Alam,2014).
\end{abstract}


Following the classical economic theory, the services have long been considered as non-productive. A. Smith, D. Ricardo, J.S. Mill, J.B. Say or K. Marx considered the usefulness of these activities as they facilitated the connection between different economic agents, but without considering the respective activities as creators of value. The new economic theories reconsider the role of services in the economic development, revising the conception of economic growth. According to this approach, the services are considered as important factors in creation of material and spiritual wealth. Thereby, a research conducted through using the databases of the Organisation for Economic Co-operation and Development [herein referred to as OECD] and The World Trade Organization pointed out that services represent $30 \%$ of the value created in the value chain of the manufacturing sector (Gurria, 2014). Currently, the services no longer only link the different phases of production, but tend to become distinct actions in the global value chain, contributing to the definition of business models and new products. The concept of "servicification of the economy" expresses the growing share of services in the final value of manufactured goods; this phenomenon is favored by a number of factors as, the cost-cutting efforts trough the increasing of the efficiency, the large geographic distribution of value chains, the emergence of new technologies, and the desire to improve customer relationships.

\section{Background and related work}

The first division of economic sectors in primary, secondary and tertiary was initially proposed, by Fisher, in 1934, and the services sector was defined as representing the reunion of the 'activities producing a non-material output' (Clark, 1940 , p. 182). Based on the subsequent divisions of the services sector, newer opinions in the field try to express the existence of the quaternary (the knowledge economy) and the quinary sectors. The quinary sector meets together different heterogeneous activities, such as the non-paid public services; the top government and science officials and executives in healthcare and culture; some economists also include, within the quinary sector, the domestic activities. Some authors outline the lower productivity and receptivity to technical progress specific to the services sector (Clark, 1940, pp. 347-350; Fourastié, 1989, pp. VIII-XII), whereas other views strongly argue this perception (Mark, 1983; Kutscher \& Mark, 1983; Nilsen, 1984). Nevertheless, the importance of the productivity is limited, as long as the activities in the tertiary sector address superior needs than the material goods, considering the specific hypothesis of the 'hierarchy of needs' (European Central Bank [herein referred to as ECB], 2006, p. 19).

Although there has not been achieved yet a consensus between the economists regarding the clear definition of the economic sectors (Shelp, 1981, pp. 10-13), the 'Law of the Three Sectors', as was called this economic model, explains the relationship between the economic growth and the distribution of the workforce (Wolfe, 1955). The economic progress leads to a shift in employment and in investments from the primary sector to the secondary sector and further to 
Significant Interdependencies of the Services Sector in the Romanian Economy

the tertiary sector (Lengelle, 1966, pp. 8-9). The increased productivity favors increased production and, implicitly, the consumption; the saturation with foodstuff (or, more generally, agricultural products) directs the consumers to manufactured goods and then to services. Accordingly, the workforce is mainly oriented towards the sector which has the best capacity to meet the consumers' demand. The migration of labor resources to the services sector, as result of the excessive demand for the activities deployed in the tertiary sector may lead to a shortage of resources in the goods-production sectors (Corden \& Neary, 1982).

The analyzes conducted in European countries and compared with the United States, Japan or Asia, highlighted different patterns of the evolution in employment of the three sectors in the nineteenth and twentieth centuries. In Europe, the industrial sector constantly attracted superior workforce than in the United States or in Japan. Therefore, in 2002, the percentage of the industrial employment accounted for $18.2 \%$ in European Union versus $12.1 \%$ in the United States, whilst the share of the workforce in services was $69.2 \%$ in Europe and about $79 \%$ in the USA (ECB, 2006, p. 17). The main feature of the services sector in Europe in represented by its cross-country homogeneity both in terms of relative contribution in the economy and in employment, whereas in Asia, it is noticeable just the high degree of heterogeneity among countries (Ghani, 2010; Park and Shin, 2012, pp. 7-9). Also there were noticed important differences between the Europe countries; by the 1970s, the United Kingdom, Belgium, Switzerland, Germany, counted higher industrial employment rates than in other European countries (Kaelble, 1998). The maintaining of a high rate in European industrial employment is also based on the historical, economic, demographic and social background. Thereby, in supporting of the industrial employment, are noticeable both the role of exports and the mobility of the young labor force, of whose age of setting up a family is later in Europe. On the other hand, the growth in imports, the density of population and the immigration are expected to be correlated directly with the development of services.

At the same time, as the relationship between the production of goods and their consumption is reciprocal, the growth of the three sectors is, to a certain extent, complementary (Urquhart, 1984). The orientation of workforce towards the services is also explainable by the dynamics of demand for activities that belong to this particular sector (Dumontier, 1965, p. 978).

The structuring of the economic sectors upon the criteria of the degree of integrating of the technical progress and their specific productivity is currently considered as limited, as many of the activities in the tertiary sector use advanced technologies and provide services, for example, to the industrial sector. 
Silvia Elena Iacob, Mihai Mieilă, Marcela Ștefan, Ioan Radu Petrariu

\section{Study methodology}

The economic importance of the tertiary sector can be evaluated through specific measures, as the share of employment in the services sector in total employment, the contribution of services in total value added, the number of active companies in services, or the value of investments in the sector. The following analysis is conducted with the aim of evaluate the contribution of services to the Romanian economy, considering the contribution of the sector to Gross Domestic Product [GDP] and employment.

The method used is represented by the analysis of the secondary data from national and international organizations: the National Institute of Statistics of Romania [herein referred to as INS], the World Bank, the OECD, and the Eurostat. The analysis of the services value added in GDP is based on a dynamic approach, covering a period of 26 years, and using of descriptive statistics aimed to highlight the evolution of the tertiary sector in the context of different changes in the Romanian economy and in comparison with other economic sectors. Then, through using the least squares regression, it is evaluated the existence of correlations between:

- the share of employment in services, (as percentage of total employment) and the share of value added in services (as percentage of GDP);

- the share of employment in services, (as percentage of total employment) and the employment in services, female (\% of female employment);

- the growth rate of GDP per capita and the share of value added in services (as percentage of GDP).

\section{The evolution of services and the contribution of economic sectors to the country GDP}

For the European Union [herein referred to as EU] countries, the last decade has been decisive in moving from the manufacturing and extractive industries (and in some cases from agriculture) based-economies towards the service-based economy. In 2004, the tertiary sector accounted for about $70 \%$ of GDP in the EU25, still under by comparison to $77.36 \%$ of the United States, but superior to Japan (68.57\%) (Kemekliene et. al., 2007, p. 8). However, the structural differences between the economies of the EU Member States remain noticeable and difficult to mitigate.

Concerning the Romanian economy, it has undergone a long transition towards a market-based economy. At the end of this transition, the shares of the agriculture and of the industry in total value added have been significantly diminished in favor of services. In the last five years of the communist regime, the Romanian industry contributed by $46 \%-47.3 \%$ to the country GDP. At the same time, the contribution of agriculture was $13.5 \%-14.9 \%$, and of the constructions, $5.5 \%-6.9 \%$. On the other hand, an important factor in influencing of the structural changes in the Romanian economy has been represented by the process of joining the European Union. 
Significant Interdependencies of the Services Sector in the Romanian Economy

The evolution of the share of industry, agriculture and services in total value added after 1990, along with the GDP per capita [p.c.] growth rate are represented in the figure 1.

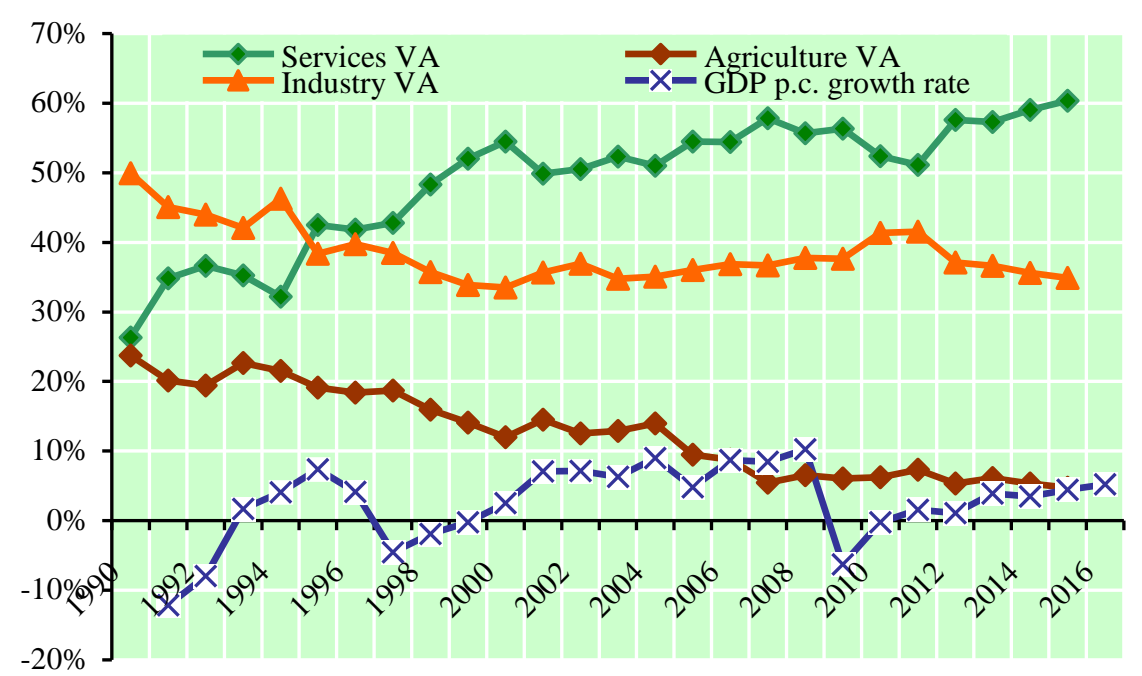

Figure 1. The share of agriculture, industry, and services value added in GDP and p.c. GDP growth rate

Analyzing the chart, there may be observed the upward trend evolution in the services sector, starting from a share of $25 \%$ in 1990 and reaching $60 \%$ in 2015. Also, there are noticeable the sharp decline of agriculture, from $21.5 \%$ in 1990 to about $5 \%$ in 2015, and the diminution in the share of industry from about $50 \%$ in 1990 to only $35 \%$ in 2015 . The Romanian economy has steadily increased by 5-10\% every year, except the two periods of economic crisis (1995-1997, 20072009), followed by a slower resumption of the upward trend (up to 5\% per year).

One of the aspects of interest in this respect regards the service providers in the Romanian economy and their evolution over the last 20 years. From the analysis of the services evolution upon to the size of the enterprises, it is noticeable the important share of the small entities, which employs less than 50 persons (Figure 2).

Overall, there is an upward trend in the total value of turnover until 2007, a period of crisis between 2008 and 2010, followed by the resumption of the upward trend. The turnover value in 2007 was exceeded hardly in 2015; provided, the analysis is in current prices, that is, a value by $35 \%$ lower in real terms. 
Silvia Elena Iacob, Mihai Mieilă, Marcela Ștefan, Ioan Radu Petrariu

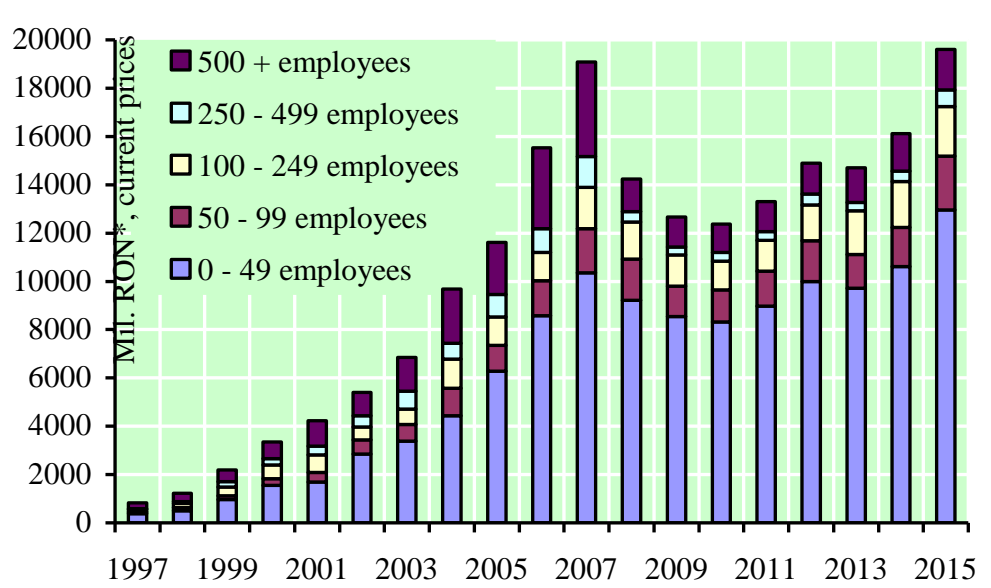

Figure 2. The evolution of the value and structure of market services provided to the population, by size classes of enterprises (in current prices)

At the same time, it is obviously the massive reduction of the share in turnover of entities over 500 employees, from $21.5 \%$ in 2006 , to $9 \%$ beginning with 2008. This development may also be the result of a major restructuring of the very large enterprises in the sector, provided the context of the financial crisis.

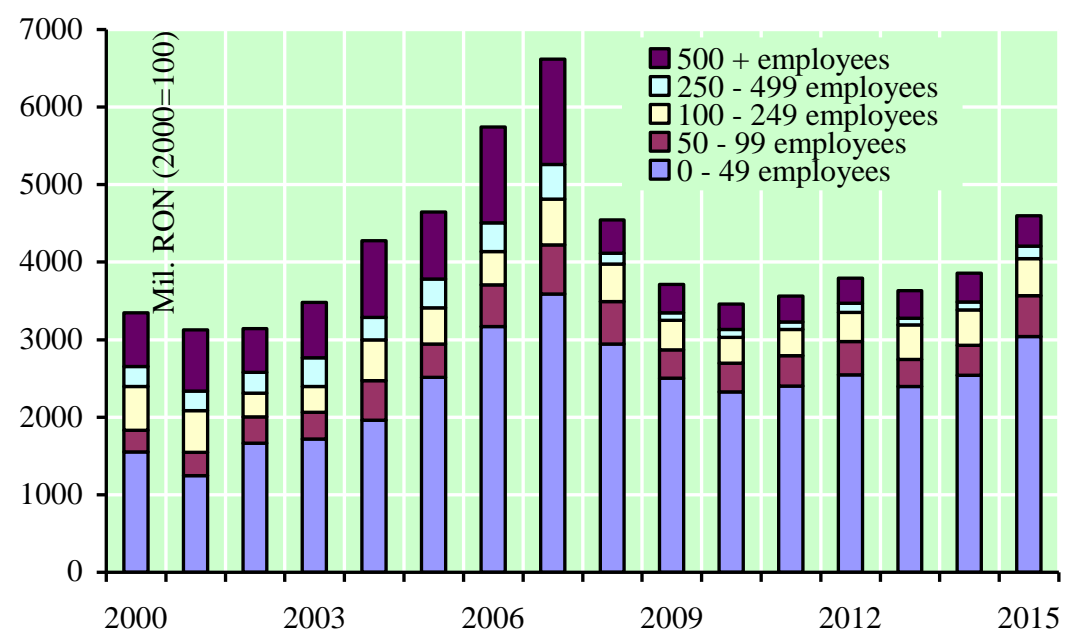

Figure 3. The evolution of the value and structure of market services provided to the population by size classes of enterprises (in constant prices, $2000=100$ )

As the period before 2000 was characterized by high levels of inflation, as well as by other distortions in the economy, for the accuracy purposes the analysis was deepened considering constant prices and the period beginning with the year 2000 (Figure 3). 
Significant Interdependencies of the Services Sector in the Romanian Economy

The evolution of the services market in constant prices express a dynamics that is not as spectacular as it looks in current prices. In fact, the market is far from the potential shown in 2007; in fact, 2015 is the first year when there is observed a rebound, comparable to the situation in the first year of crisis in the field (2008), in Romania.

\section{The relationship between the contribution of services in country} GDP and the GDP growth

It is generally presumed a link between the development of the tertiary sector and the economic growth; thereby, the share of this sector reflects the level of economic development of the country (Lengelle, 1966, p.12). Studies conducted in various geographical contexts found direct correlation between the share of the services value added in county GDP on the one hand, and the general level of the country development (Kongsamut et. al., 2001; Kemekliene et. al., 2007, p. 10; Ahmed and Ahsan, 2011, p. 7; Mujahid and Alam, 2014).

Following this approach, and based on the time-series specific to Romania, the above correlation, considered per se, or for various proxies for the GDP (as the Gross National Income, or GDP per capita), or dividing the period considered in two sub-ranges, etc., returned statistically insignificant results. However, the correlation between the share of value added of services in GDP on the one hand, and the per capita GDP growth rate on the other hand, returned significant results (Figure 4).

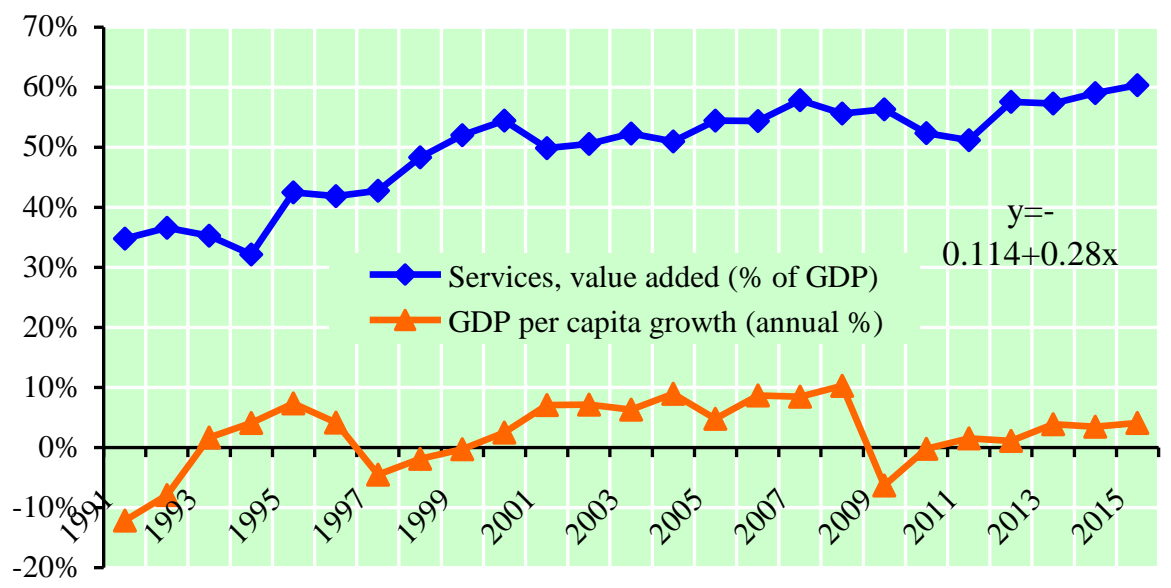

Figure 4. The evolution of GDP growth per capita and the share of the tertiary sector in Romania

Based on the available data, it results that, for the considered time range, the augmentation by one percentage point in the share of services in country GDP 
accounts for 0.28 in GDP per capita growth. This result is significant at 5\% level of significance, as well as the value of F-statistics for the considered model.

\section{Contribution of the tertiary sector to employment in Romania}

Global studies emphasized the existence of a correlation between the development of the tertiary sector and the increase in employment and productivity. This type of examples can be met in countries like Australia, Canada, the USA, Luxembourg or Slovakia, especially through highly skilled jobs in financial services, production, education and healthcare. However, the correlation between growth of services and employment, for the period 1990-2002, reported limited results in countries like Korea, Spain, Italy or Poland; also the contribution to productivity growth was reduced in Spain, France, Italy or the Netherlands (OECD, 2005, pp. 5-6). There are multiple causes of these differences, explained for example by the differences regarding the country public policies to support employment, or the effects of globalization, especially as regards the outsourcing of manufacturing services from one country to another.

In the EU Member States, there has also been a shift in the employment structure by increasing the share of services, along with its decline in industrial and agriculture sectors. This development was explained by the increased demand for services, following the increase in revenues and the movements in relative prices; according to the Clark-Fischer model above mentioned, the demand saturation for agricultural and industrial goods has stimulated demand for services, some of them with a spectacular evolution, as for example the leisure and leisure services (Fisher, 1935 , p. 29). Another noticeable development is represented by the overlap between the entry of the women labor force into the labor market (Ginsberg and Vojta, 1981; Urquhart, 1984) and the aging process of the European population; the increase of needs for care of this category of persons was mostly met by services provided by the female population.

On the other hand, the technological evolution exerts significant influences on employment in the services sector. Thereby, in the fields of telecommunications and finance, the technological developments have led to a decrease in the workforce and the demand for additional professional skills for the employees; the extending of the e-commerce and using of the Internet to purchase online services represents another noticeable example in this respect (Alford \& Page, 2015). The increasing outsourcing in services as accounting, legal advice, IT\&C, represents a factor of their development, which have favored employment (Mujahid and Alam, 2014). However, the major risk is represented by the abroad outsourcing, in favor of countries with a lees costly labor; in this case, the employment at the national level is affected. Nevertheless, the relocation of services from countries with higher salaries to those with lower ones is limited by some factors: lack of skilled employees, the language and cultural barriers, the incurred costs, and the need for proximity between the service provider and customer (Kemekliene et. al., 2007, pp. 46-47). In close connection with the need to reduce the salary costs stands also the 
Significant Interdependencies of the Services Sector in the Romanian Economy

recourse to immigrant labor, as the services traditionally represents the sector in which this labor is integrated the most facile (Kaelble, 1998, pp. 26-27). The free movement of labor force between the European Union Member States has led to benefits in terms of salary costs for some countries, whilst for others it has caused negative consequences, in the form of shortage in skilled labor. Studies conducted by the OECD have highlighted that the immigrant workers tends to occupy lowskilled jobs in spite of their higher qualification, leading implicitly to strong competition with the domestic workforce employed on similar posts and having reduced qualification (Kemekliene et. al., 2007, p. 49).

The next step in our analysis is to examine the existence of a relationship between the evolution of the tertiary sector contribution in GDP and the evolution of share in employment of this sector in total employment. The graphical representation (Figure 5) highlights the upward trend of the two variables in the analysis period, besides the regression equation, considering the labor force as the input variable.

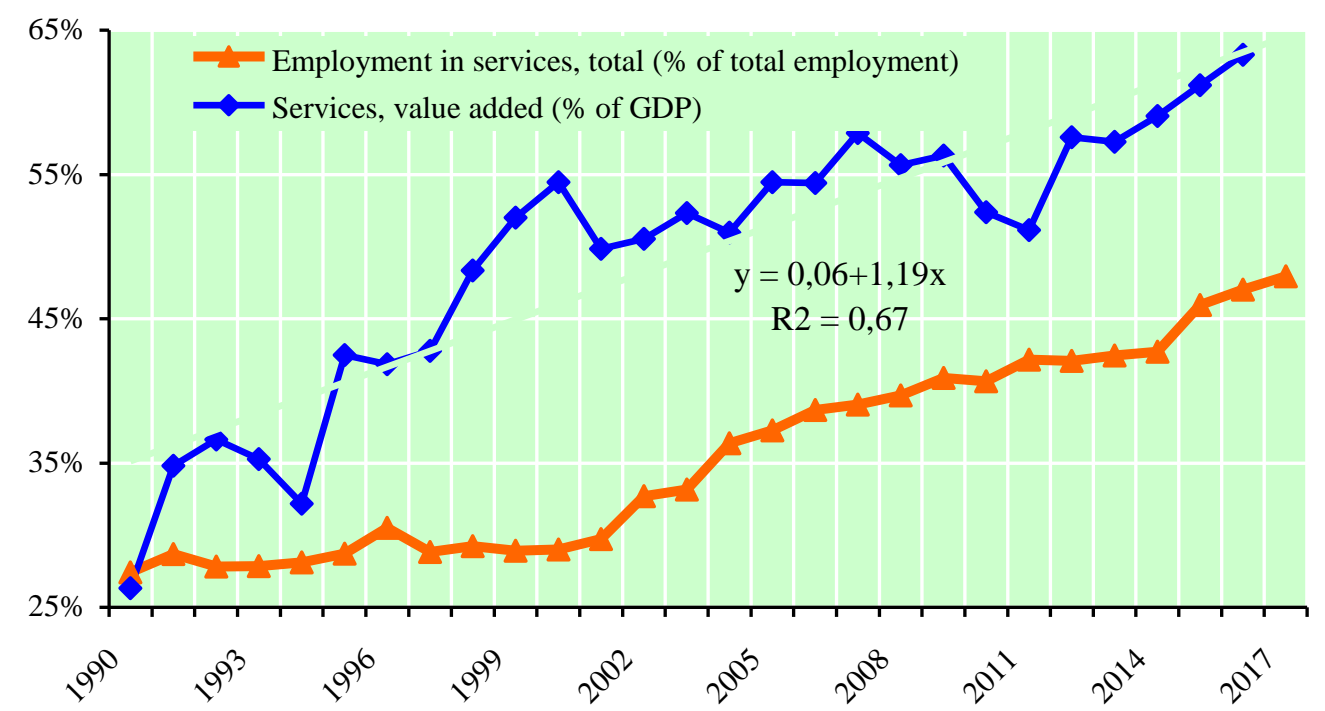

Figure 5. The correlation between the share of the labor force in services and the value added share of the tertiary sector in GDP in Romania (1990-2014)

Based on the data from the World Bank statistics for the period 1990-2014, results that each additional percentage of labor employed in services explains, on average, a $1.19 \%$ increase in the share of services in the national economy; this result is significant at 5\% level of significance. From the value of adjusted $R$ square, equal to 0.66 , and the $F$-statistics value of 46.99 , significant at $1 \%$ level of significance, results the validity of the correlation between the two considered 
Silvia Elena Iacob, Mihai Mieilă, Marcela Ștefan, Ioan Radu Petrariu

variables.

Since the economic and social conditions over the analyzed period evolved substantially, as they can be evaluated as heterogeneous, there were considered deepen of the analysis through division of the considered period into two time rages: 1990-2001 and 2002-2014, respectively. From the available data (Figure 6) results that, for the period before 2001, the growth of the share of services in GDP for each percentage of the labor force occupied in the sector is, on average, of $3.72 \%$.

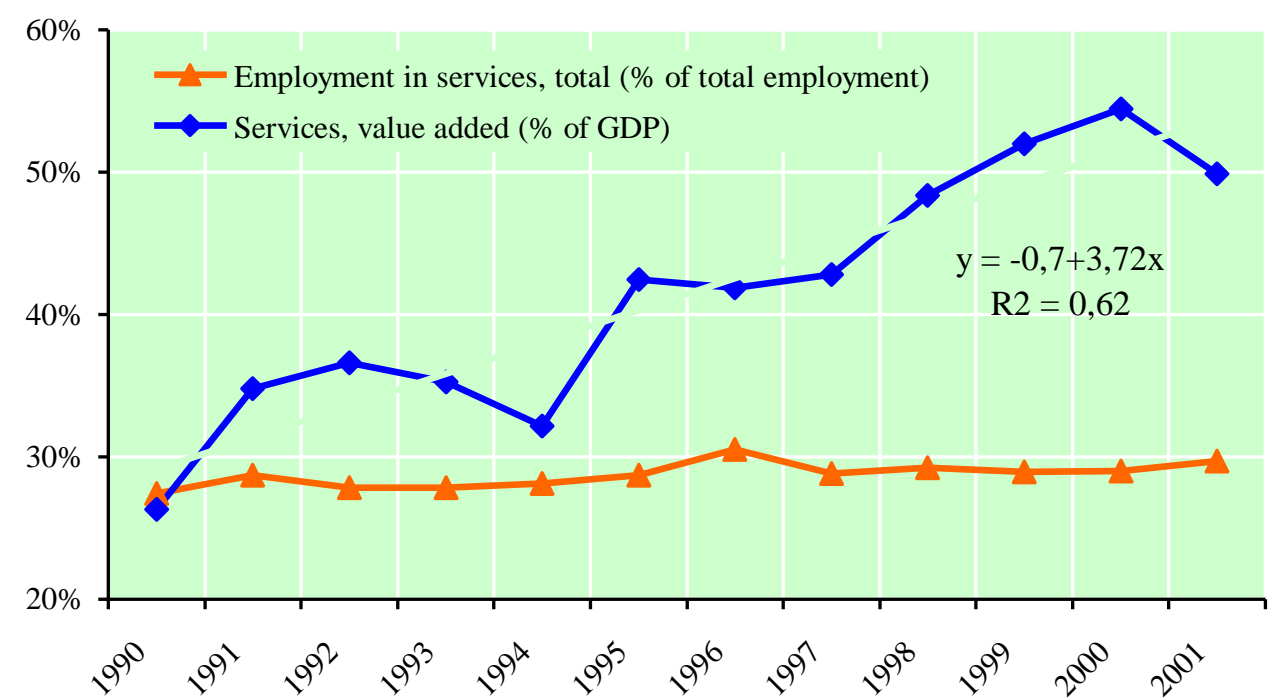

Figure 6. The correlation between the share of the labor force in services and the value added share of the tertiary sector in GDP in Romania (1990-2001)

The situation is obviously different in the period after 2001, when the same percentage is only $0.56 \%$ (Figure 7).

The results for both two considered sub-periods are significant for a significance level of 5\%, as well as in case of $F$-statistics. This development can be interpreted through a situation emerging from more developments: the economic crisis and the reduction of employment in the sector during 2008-2011, the diminution of the marginal returns, and, not least, by the lower productivity in services, as evidenced in the literature and extensively used by the 'supporters' of economic industrialization and re-industrialization. However, the situation of low ratio of the value added in the tertiary sector compared to that of goods producing sectors is widely emphasized in literature and consistent to other case studies above mentioned (OECD, 2005, p. 13; ECB, 2006, p. 19). 


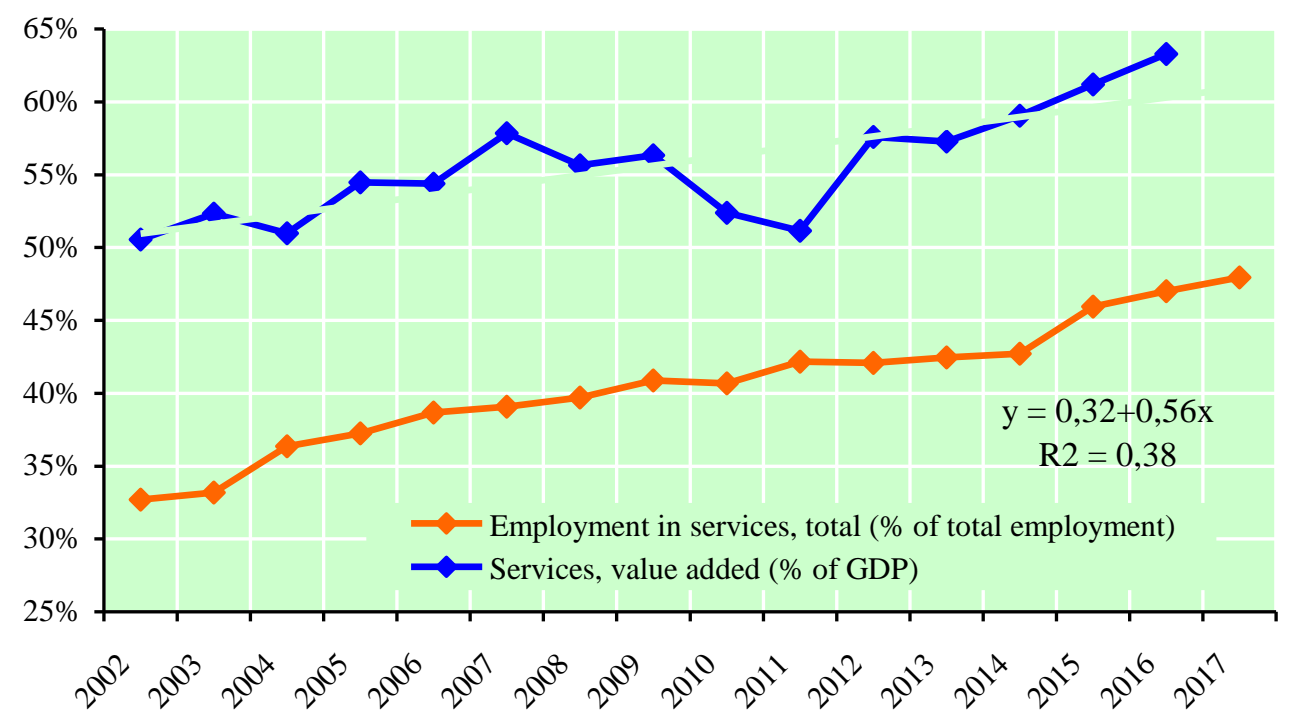

Figure 7. The correlation between the share of the labor force in services and the value added share of the tertiary sector in GDP in Romania (2002-2014)

Some scholars (Lopez-Garcia, 2003, p. 38) argue about the existence of a relationship between the employment rate in the services sector and the unemployment level, explaining the higher unemployment as a consequence of the underdevelopment in the tertiary sector. However, previous studies conducted based on European available data could not highlight the existence of such a correlation between the two economic phenomena (Kemekliene et. al., 2007, p. 12).

Another paradigm investigated regards the correlation between the share of the tertiary sector in the economy and the share of female participation in the labor force. In Europe, as well as in other countries, there was noticed that the female workforce occupies the highest share in the total labor of the service sector. The situation is explained by numerous factors related to national employment policies, national demographic and cultural characteristics, and by the specific of the various types of services.

Based on the available data in the OECD database regarding the evolution of the two variables in the sample countries, results that each percentage increase in the share of the employed population in the services sector accounts, on average, for $0.775 \%$ of the increase in the employment rate among women. This result is significant for a 5\% level of significance, the adjusted R-squared is equal to 0.68 , and the F-statistics, of 56.25 is significant for $1 \%$ level of significance. In 
summary, from the processed data results that, globally, there is a direct and significant link between the labor force share in the services and the general employment rate of the female population.

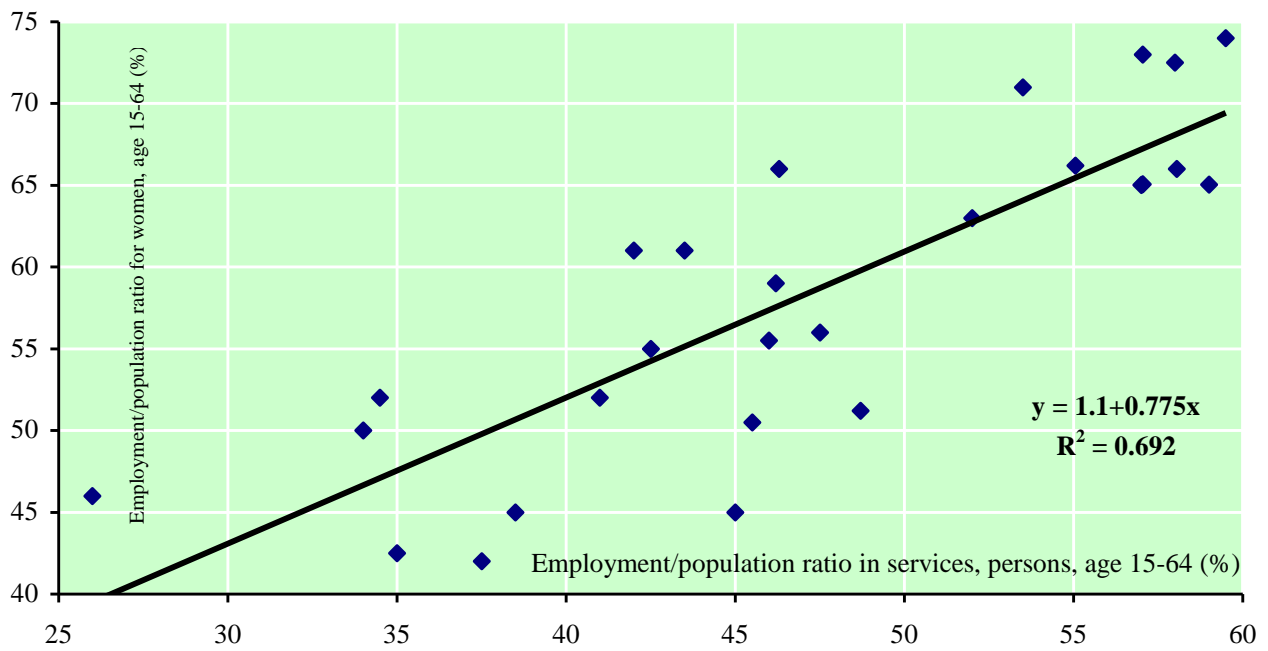

Figure 8. The relationship between the employed population in services and the women employment

In order to evaluate the correlation between the share of the labor force employed in services in Romania and the share of women participation in the labor force, there were considered the corresponding time series for the range 19902014. The graph in the fig. 9 and the corresponding analytical results depict an atypical situation, characterized by a strong augmentation in workforce employed in services amid a general trend of diminution for the share of female participation in the workforce; the development may be explained by deep restructuration of the national economy through the considered period. However, the result is significant a for $1 \%$ level of significance, the adjusted $R$-squared is equal to 0.77 , and the value of $F$-stat, of 89.60 , is significant for $1 \%$ level of significance.

In spite of this specific result, in the literature is widely emphasized that, at the global level and in the current social life, the increasing of the share of women participation in the labor force could lead to an increase in the share of services in employment and in added value. Recent researches in the field and based on relevant results point out that increasing the share of services in the economy represents a real key to increase the participation in labor force, in particular by providing the type of jobs needed to attract staff from different groups (part-time contracts, evening and night activities, and low-skilled staff) (OECD, 2005, p. 15). Based on the same results, it can be argued that an increase in labor force participation can represent a new impetus for the development of the service sector. 


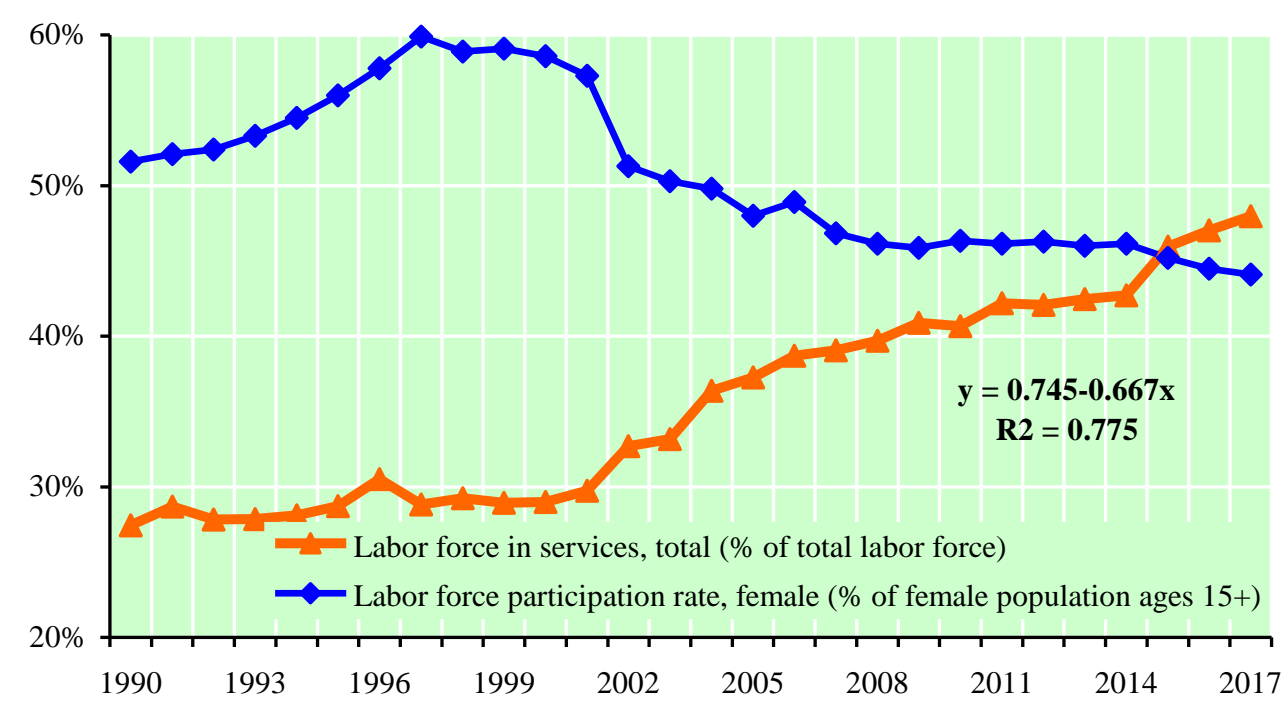

Figure 9. The correlation between the share of the labor force employed in services and the share of female participation in the labor force in Romania

\section{Conclusions and future research directions}

The paper tries to highlight the global trend of increasing in the share of services, both in national economies and in the global one, as a trademark of economic progress. In Romania, the share of the tertiary sector is still below the European average. However, the augmentation of the services sector, which more than doubled its share in country GDP in the last fifteen years, is remarkable. Another important result is represented by the significant relationship, for the Romanian economy, between the contribution of services in GDP and the GDP per capita growth rate, namely the augmentation by one percentage point in the share of services in country GDP accounts for 0.28 in GDP per capita growth.

At the same time, the development of services implies important and positive consequences on employment. Thus, based on studies above presented in literature, there has shown that changes in the services sector generate changes in employment; the main specific of the tertiary sector is the increased need for labor. In addition, the growing outsourcing trend and the migration of labor represent challenges that the services sector has to deal with, both at European and international level. In the case of Romania, the statistical analysis highlighted the existing relationship between employment in services and the share of services in country GDP. The contribution of the growth of the labor force in services to the share of GDP in services was more pronounced between 1990-2001 and lower in the period 2002-2014. 
In contrast with the evolution in other countries, in Romania, the increase in the share of labor employed in services was not accompanied by an increase in the share of female participation in the labor force. Moreover, the diminution of employment in feminine population amid the share growth of the labor force in the tertiary sector determined a negative but significant correlation between these two phenomena.

The future research directions regarding the tertiary sector in Romania may encompass, but not limited, the types of services with the top contribution in employment, the features of the workforce and the factors supporting the development in the field, beyond the mere emergence of new entities or the development of turnover as result of market growth. In terms of economic growth, another aspect that can be deepened in future research is the relationship between the evolution of the share of tertiary sector in GDP and the evolution of the national trade balance, knowing the higher share of industrial employment in countries with considerable exports. The important share of small entities in the services sector highlights the possible fragility of the sector in the event of an economic downturn, and it would be interesting to study how the number of entities in services on the Romanian market has evolved over time and what are the main issues that they have to deal with.

Starting from the established relationship between the share of services in GDP and the GDP growth, and consistent with the conclusions of other researches, we consider that the development of the service sector will represent an important source of economic growth both at national and global level. However, this development is conditioned by the sector's ability to integrate the technological progress and by the increase in productivity, as in other economic sectors.

One of the challenges the Romanian tertiary sector will have also to deal with is represented by the possibilities of recruitment of skilled personnel, able to use the new technologies in a gloomy evolution. In the context of youth labor migration and the difficulties faced by the national education system, the involvement of service companies in the preparation of the future labor force may represent a viable solution.

The tertiary sector in Romania is still at the beginning of maturity and its development must be based on the intensive side. A functional and performing service sector is essential to the economic performance and well-being of citizens. The reforming of the specific policies at European level may represent an important opportunity for boosting productivity, innovation and employment. It can also help strengthen the ability of the Romanian economy to adapt to changes produced in the context of market services globalization. 
Significant Interdependencies of the Services Sector in the Romanian Economy

\section{REFERENCES}

[1] Ahmed, A., Ahsan, H. (2011), (2010), Contribution of Services Sector in the Economy of Pakistan; PIDE Working Papers No. 79. Islamabad: Pakistan Institute of Development Economics;

[2] Clark, C. (1940), The Conditions of Economic Progress; London: MacMillan \& Co. Ltd.;

[3] Cornwall, J. (1977), Modern Capitalism: Its Growth and Transformation; London: Martin Robertson;

[4] Corden, M.W., Neary, J.P. (1982), Booming Sector and De-

Industrialization in a Small Open Economy; The Economic Journal, 92(368): 825-848;

[5] Dumontier, J. (1965), Généralisation de la loi des trois secteurs

[Generalization of the law of the three sectors]; Revue économique, 16(6): 974978 ;

[6] European Central Bank (2006), Competition, Productivity and Prices in the Euro Area Services Sector (Occasional Paper Series no. 44); Frankfurt am Main: Task Force of the Monetary Policy Committee of the European System of Central Banks;

[7] Fischer, A.G.B. (1935), The Clash of Progress and Security; London: Macmillan;

[8] Fourastie, J. (1949/1989), Le grand espoir du XX $X^{e}$ siècle: Progrès technique, progrès économique, progrès social [The great hope of the twentieth century: Technical progress, economic progress, social progress]; Paris: Gallimard; [9] Ghani, E. (Ed.) (2010), The Service Revolution in South Asia; New Delhi: Oxford University Press;

[10] Ginsberg, E., Vojta, G. (1981), The Service Sector of the U.S. Economy; Scientific American, 244 (March): 48-55;

[11] Gurría, Á. (2014), Creating Value in an Interconnected World: The Role of Services, available at: http://www.intracen.org/article/Creating-value-in-aninterconnected-world-The-role-of-services/;

[12] Kaelble., H. (1998), Le changement structurel de l'emploi en Europe aux XIXe et XXe siècles. [Structural change in employment in Europe in the $19^{\text {th }}$ and $20^{\text {th }}$ centuries]; Histoire, économie et société, 17(1); 13-37;

[13] Kongsamut, P., Rebelo, S., Xie D. (2001), Beyond Balanced Growth; Review of Economic Studies; 68(4): 869-882;

[14] Kemekliene G., Connolly H., Keune, M., Watt, A. (2007), L'emploi dans les services en Europe : Aujourd'hui et demain. [Employment in services in Europe: Today and tomorrow]; Bruxelles: ETUI-REHS;

[15] Kutscher, R .E., Mark, J.A. (1983), The Service-producing Sector: Some Common Perceptions; Monthly Labor Review, 106(4): 3-12; 
Silvia Elena Iacob, Mihai Mieilă, Marcela Ștefan, Ioan Radu Petrariu

[16] Lengelle, M. (1966), The Growing Importance of the Service Sector in Member Countries; Paris: Organization of Economic Cooperation and Development;

[17] Lopez-Garcia, P. (2003), Labour Market Performance and Start-up Costs: OECD Evidence (CESIFO Working Paper, no. 849); London: Centre for Economic Performance, London School of Economics and Political Science;

[18] Mark, J. A. (1982), Measuring Productivity in Service Industries; Monthly Labor Review, 106(6): 3-8;

[19] Mujahid, H., Alam, S. (2014), Service Sector as an Engine of Growth: Empirical Analysis of Pakistan; Asian Economic and Financial Review, 4(3), 377-386;

[20] Nilsen, D. (1984), Employment in Durable Goods Anything but Durable; Monthly Labor Review, 107(2): 15-24;

[21] Organisation for Economic Co-operation and Development (2005), Growth in Services - Fostering Employment, Productivity and Innovation; available at: http://www.oecd.org/general/34749412.pdf;

[22] Park, D., Shin, K. (2012), The Service Sector in Asia: Is It an Engine of Growth? (ADB Economics Working Paper Series, No. 322); Manila: Asian Development Bank;

[23] Shelp, R.K. (1981), Beyond Industrialization: Ascendency of the Global Service Economy; New York: Praeger Publishers;

[24] Urquhart, M. (1984), Employment Shift to Services: Where Did it Come from? , Monthly labor review, 107 (4): 15-22;

[25] Wolfe, M. (1955), The Concept of Economic Sectors; The Quarterly Journal of Economics, 69(3): 402-420. 